\title{
Responses of lake phytoplankton communities to changing inorganic nitrogen supply forms
}

\author{
Gabriele Trommer $^{1,2}$ (1) $\cdot$ Monika Poxleitner ${ }^{1} \cdot$ Herwig Stibor $^{1}$
}

Received: 6 September 2018 / Accepted: 3 January 2020 / Published online: 17 January 2020

(c) The Author(s) 2020

\begin{abstract}
A shift has been predicted in future nitrogen emission scenarios from nitrous oxide to higher proportions of ammonium compounds. To investigate the interaction between increasing nitrogen load and varying nitrate:ammonium ratios $\left(\mathrm{NO}_{3}{ }^{-}: \mathrm{NH}_{4}{ }^{+}\right)$, we performed a mesocosm experiment in an oligotrophic lake in southern Germany. We fertilized mesocosms with both roughly natural and four times the natural nitrogen wet deposition amounts in molar $\mathrm{NO}_{3}{ }^{-}: \mathrm{NH}_{4}{ }^{+}$ratios of 4:1 and 1:4. We observed greater phytoplankton biomass in treatments with a relatively higher ammonium supply, but not in those with nitrate and total nitrogen load. Ammonium significantly increased the total chlorophyll $a$ concentrations, and especially the growth of small nanophytoplankton species. The effects observed indicate that $\mathrm{NH}_{4}{ }^{+}$was taken up preferentially and that spring phytoplankton in oligotrophic lakes appear to be able to respond to variations in nitrogen forms (available $\mathrm{NO}_{3}{ }^{-}: \mathrm{NH}_{4}{ }^{+}$ratios) by adjusting their community composition. Such communal changes at the base of the food web may affect higher trophic levels. Therefore, the effects of varying available forms of nitrogen should also be considered in primarily phosphoruslimited aquatic systems.
\end{abstract}

Keywords Phytoplankton $\cdot$ Community composition $\cdot$ Nitrate $\cdot$ Ammonium $\cdot$ Ratio $\cdot$ Oligotrophic

\section{Introduction}

Anthropogenic intervention in the global nitrogen $(\mathrm{N})$ cycle is an issue of major interest, as increasing $\mathrm{N}$ loads often cause measurable changes in ecosystem functioning (Vitousek et al. 2010; Paerl et al. 2014; Steffen et al. 2015). In coastal ecosystems, the effects of $\mathrm{N}$ enrichment are usually immediately visible as typical signs of eutrophication, such as hypoxia and harmful algae blooms (Paerl 1997; Diaz and Rosenberg 2008; Paerl and Huisman 2008). Besides surface runoff and groundwater input, the greatest threat is the non-point, diffuse deposition of $\mathrm{N}$ compounds via the atmosphere, which can even reach remote areas (Bergström et al. 2005; Kim et al. 2014).

Gabriele Trommer

gabi.trommer@gmx.de

1 Department II Biology, Aquatic Ecology, LudwigMaximilians-University Munich, Großhaderner Str. 2, 82152 Planegg-Martinsried, Germany

2 Present Address: Water Management Office Ansbach, Dürrnerstr. 2, 91522 Ansbach, Germany
Reactive $\mathrm{N}$ compounds include nitrogen oxides $\left(\mathrm{NO}_{x}^{-}\right)$ and ammonium $\left(\mathrm{NH}_{4}{ }^{+}\right)$, which have been increasing globally due to human activities over the last century (Galloway et al. 2003). A recent analysis revealed that $\mathrm{NO}_{x}{ }^{-}$production is currently more or less stable, but that $\mathrm{NH}_{x}^{+}$production continues to rise due to steadily rising human food requirements (Ciais et al. 2013). It is predicted that $\mathrm{N}$ fertilizer surpluses will continue to increase by a global average of $23 \%$ until 2050, and by up to $75 \%$ in Latin America (Bouwman et al. 2013). This may eventually double the recent average $\mathrm{N}$ deposition in industrialized and developing countries from 10 to $20 \mathrm{~kg} \mathrm{~N} \mathrm{ha}^{-1}$ year $^{-1}$ until 2050, and to over $50 \mathrm{~kg} \mathrm{~N} \mathrm{ha}^{-1}$ year $^{-1}$ in some Asian regions (Galloway et al. 2004). Therefore, future ecosystems face not only a continual accumulation of total $\mathrm{N}$ load, but also a shift in reactive $\mathrm{N}$ sources from $\mathrm{NO}_{x}^{-}$towards reduced $\mathrm{N}$ forms.

In addition to the necessary management of total $\mathrm{N}$ load (and of course of total phosphorus) (e.g. Lewis et al. 2011; Paerl et al. 2016), it is recommended that, whenever possible, nitrogen management should focus on the control of bioavailable $\mathrm{N}$ forms (Lewis et al. 2011). The rapid recycling of inorganic and organic $\mathrm{N}$ complicates the management of specific bioavailable $\mathrm{N}$ forms. This is especially pertinent in 
$\mathrm{N}$-limited coastal waters, where $\mathrm{NH}_{4}{ }^{+}$stimulates greater biomass development than nitrate $\left(\mathrm{NO}_{3}{ }^{-}\right)$when both are supplied in equal quantities (Paerl 1997). It is presumed that $\mathrm{N}$ is the main limiting macronutrient globally (Vitousek and Howarth 1991; LeBauer and Treseder 2008), hence the focus on both $\mathrm{NO}_{3}{ }^{-}$and $\mathrm{NH}_{4}{ }^{+}$in $\mathrm{N}$-limited systems. In terms of energy, the qualitative differences in $\mathrm{NO}_{3}{ }^{-}$and $\mathrm{NH}_{4}{ }^{+}$ supplies should influence primary production. In aquatic ecosystems, the primary producers can assimilate $\mathrm{NH}_{4}{ }^{+}$ directly, without need for costly enzyme activity to reduce $\mathrm{NO}_{3}{ }^{-}$(Eppley et al. 1969b; Falkowski 1975). Physiological adjustments of phytoplankton, such as suppressed nitrate reductase synthesis and activity, can occur when $\mathrm{NH}_{4}{ }^{+}$concentrations exceed 0.5-1 $\mu \mathrm{M}$ (Eppley et al. 1969a). Various laboratory studies have observed differential utilization of N compounds by phytoplankton (Dortch 1990; Levasseur et al. 1993). A preference for $\mathrm{NH}_{4}{ }^{+}$as the $\mathrm{N}$ source, for example, was noted in algal groups such as flagellates, green algae and cyanobacteria (Blomqvist et al. 1994; Dortch 1990; Domingues et al. 2011; Donald et al. 2013; Flores and Herrero 2005; Glibert et al. 2016), which have higher uptake affinities for this compound (Litchman et al. 2007). However, growth rates may be higher under $\mathrm{NO}_{3}{ }^{-}$supply, especially for a range of diatoms (Dortch 1990; Levasseur 1993; Litchman et al. 2007). In addition, size- or surface-tovolume ratios affect nutrient uptake, and smaller algae are known to be good competitors for nutrients such as phosphorus (P; Smith and Kalff 1982), as well as for $\mathrm{NO}_{3}{ }^{-}$and $\mathrm{NH}_{4}{ }^{+}$ (Eppley et al. 1969b; Hein et al. 1995; Wafar et al. 2004). On the other hand, there is evidence that larger algae species perform better with $\mathrm{NO}_{3}{ }^{-}$, and that they can also accumulate nutrients in vacuoles (Stolte and Riegman 1995). This was observed in diatoms and dinoflagellates, where maximum $\mathrm{NO}_{3}{ }^{-}$uptake rates per cell increased with cell size (Aksnes and Egge 1991; Litchman et al. 2007). Since the traits of phytoplankton groups differ with regard to nutrient use, a shift in $\mathrm{N}$ sources may alter the phytoplankton community composition through resource competition (Tilman 1977; Sommer 1985). Several field studies demonstrated that N forms are able to change the relative abundance of diatoms and cyanobacteria (Hutchins et al. 2003; McCarthy et al. 2009), and the relative contribution of chrysophytes and dinoflagellates to total phytoplankton biomass (Blomqvist et al. 1994; Poxleitner et al. 2016).

In the traditional context of ecological stoichiometry theory and nutrient limitation, attention has largely been focused on the general $\mathrm{N}: \mathrm{P}$ supply ratio in ecosystems. The subject of $\mathrm{N}$ addition in $\mathrm{N}$-excess systems has rarely been directly investigated (Poxleitner et al. 2016; Trommer et al. 2017; Lorenz et al. 2019). Lakes are naturally co-limited by $\mathrm{N}$ and $\mathrm{P}$, or are seasonally limited by either of the two nutrients (Elser et al. 2007; Sterner et al. 2008; Paerl et al. 2016). On average, seston is characterized by a mean elemental ratio of $\mathrm{N}: \mathrm{P}$ between 16:1 (Redfield ratio) and 20:1 (Sterner et al. 2008). Therefore, in rather P-deficient systems at dissolved N:P ratios beyond 45:1 (Klausmeier et al. 2004), additional $\mathrm{N}$ was not initially expected to have a considerable effect on the natural phytoplankton. However, the nutrient identity of $\mathrm{N}$, and not only supply rate, has been described to affect uptake and internal concentration of other nutrients such as $\mathrm{P}$ (Bracken et al. 2015). It has recently been shown that total $\mathrm{N}$ load and bioavailable $\mathrm{N}$ forms do matter and do indeed influence the primary production, including in rather P-limited systems (Lewis et al. 2011; Paerl et al. 2016). Furthermore, investigations have revealed that manipulating $\mathrm{N}$ availability in mesocosm studies in oligotrophic lakes resulted in changes in the phytoplankton community composition (Blomqvist et al. 1994; Poxleitner et al. 2016).

Although differences in the bioavailability of $\mathrm{NO}_{3}{ }^{-}$and $\mathrm{NH}_{4}{ }^{+}$are indicated from laboratory studies, the effects of varying $\mathrm{NO}_{3}{ }^{-}: \mathrm{NH}_{4}{ }^{+}$supply ratios in natural systems are considerably less known. Experiments on $\mathrm{N}$ resource use in natural communities have either been performed with a single $\mathrm{N}$ form (Axler and Reuter 1996) or in eutrophic, $\mathrm{N}$-limited systems with combined $\mathrm{N}$ forms in constant fertilization ratios (Twomey et al. 2005; Donald et al. 2013). Furthermore, it is important to understand the potential interactions between the two nitrogen supply forms (Flores and Herrero 2005; Gruber and Galloway 2008). For example, the presence of $\mathrm{NH}_{4}{ }^{+}$ can inhibit $\mathrm{NO}_{3}{ }^{-}$uptake by a reported threshold ranging from $>0.1,1,4$, to $15 \mu \mathrm{M}$ (Dortch 1990; Dugdale et al. 2007). The degree of inhibition has thereby been demonstrated to be a function of the exposure history of algae to experimental nitrogen enrichments (Dortch and Conway 1984).

In order to investigate the impact of $\mathrm{N}$ enrichment on natural phytoplankton communities at two different $\mathrm{NO}_{3}{ }^{-}: \mathrm{NH}_{4}{ }^{+}$ supply ratios (based on realistic atmospheric $\mathrm{N}$ deposition scenarios), we performed a mesocosm experiment in an oligotrophic lake. As the lake studied is primarily P-limited in spring, we hypothesize that (1) $\mathrm{N}$ enrichment does not increase phytoplankton biomass. According to previous studies on enrichment with $\mathrm{NH}_{4}{ }^{+}$or $\mathrm{NO}_{3}{ }^{-}$(Dortch 1990; Sommer 1993; Donald et al. 2013), (2) specific algal groups, such as small flagellated or green algae, should benefit from high $\mathrm{NH}_{4}{ }^{+}$supply ratios. Lastly, (3) we expect a higher resource use efficiency for phytoplankton at high $\mathrm{NH}_{4}{ }^{+}$supply rates, since $\mathrm{NH}_{4}{ }^{+}$uptake is energetically less costly in comparison to $\mathrm{NO}_{3}{ }^{-}$.

\section{Materials and methods}

\section{Study site and experimental design}

In spring 2014 (March 11-May 28, 2014, 77 days) a mesocosm experiment was conducted in Lake Brunnsee, a kettle 
lake in Upper Bavaria, Germany $\left(47^{\circ} 15^{\prime} \mathrm{N}, 12^{\circ} 12^{\prime} \mathrm{E}\right)$. This relatively small lake (area: $0.058 \mathrm{~km}^{2}$, max. depth: $19 \mathrm{~m}$ ) can be characterized as oligotrophic, with a low total phosphorus (TP) concentration of $<0.3 \mu \mathrm{M}$ and a low chlorophyll $a$ concentration of on average $<2 \mu \mathrm{g} \mathrm{L}^{-1}$. At the time of the study, the lake water had mean concentrations of $\sim 316 \mu \mathrm{M} \mathrm{NO}_{3}{ }^{-}$and $\sim 1.2 \mu \mathrm{M} \mathrm{NH}_{4}{ }^{+}$and reached high dissolved N:P molar ratios of $\sim 1000: 1$ after winter mixing.

The experimental setup consisted of twelve enclosures made from white, opaque polyethylene foil $(150 \mu \mathrm{m}$, Biofol Film GmbH, Germany). These were sealed as closed-bottom cylindrical bags, with a length of $3 \mathrm{~m}$ and a diameter of $\sim 0.95 \mathrm{~m}(\sim 2100 \mathrm{~L})$. They were gently lifted from a depth of $\sim 8 \mathrm{~m}$, filling them with a subsample of the natural phytoplankton and zooplankton community, and then secured to anchored rafts. As the enclosures were open to the atmosphere, they were covered with a frame and transparent foil in order to prevent nutrient input through precipitation. Sensors recorded the temperature hourly, and were installed in each enclosure at a depth of $1.5 \mathrm{~m}$. On day 23, the light attenuation in the enclosures was measured with a spherical light probe (LI 1000, Licor, Lincoln, Nebraska, USA).

A $2 \times 2$ factorial design was applied (four treatments, each replicated three times) in order to test the effects of increasing $\mathrm{N}$ supply and varying $\mathrm{NO}_{3}{ }^{-}: \mathrm{NH}_{4}{ }^{+}$supply ratios (Table 1). The $\mathrm{N}$ addition was performed based on a weekly, natural deposition of approximately $2 \mathrm{mM} \mathrm{N}$ per enclosure surface $\left(\sim 0.72 \mathrm{~m}^{2}\right)$. Rain samples on the lake (Trommer, unpublished data) and monitoring data from the Bavarian Environment Agency and the German Meteorological Survey were used to estimate the natural $\mathrm{N}$ wet deposition. The mean regional precipitation was $\sim 25 \mathrm{~L} \mathrm{~m}^{-2}$ per week for the years 2012 and 2013. The concentrations of $\mathrm{NO}_{3}{ }^{-}$and $\mathrm{NH}_{4}{ }^{+}$in the rain samples were approximately $0.05 \mathrm{mM}$ respectively, which adds up to a hypothetical supply of $\sim 1 \mathrm{mM} \mathrm{NO}_{3}{ }^{-}$and $\mathrm{NH}_{4}{ }^{+}$per week and per enclosure surface. As $\mathrm{N}$ deposition is predicted to increase two- to five-fold by 2050 (Galloway et al. 2004), we decided to

Table 1 Experimental design: $\mathrm{N}$ fertilization scheme (three mesocosm replicates per treatment) with $\mathrm{N}$ quantities (1 mmol fertilization $^{-1} ; 4 \mathrm{mmol}$ fertilization $\left.^{-1}\right), \mathrm{N}$ ratios (4:1 and $1: 4$ $\mathrm{NO}_{3}{ }^{-}: \mathrm{NH}_{4}{ }^{+}$) and amounts of $\mathrm{NO}_{3}^{-}$and $\mathrm{NH}_{4}{ }^{+}$supplied in mmol and mg (twice weekly)

\begin{tabular}{|c|c|c|c|c|c|}
\hline \multirow[t]{2}{*}{ Treatment } & \multirow{2}{*}{$\begin{array}{l}\text { Fertilization scheme } \\
\text { Quantity-ratio }\end{array}$} & \multicolumn{2}{|c|}{$\begin{array}{l}\mathrm{N} \text { addition } \\
{[\mathrm{mmol}] \text { per }} \\
\text { fertilization }\end{array}$} & \multicolumn{2}{|c|}{$\begin{array}{l}\mathrm{N} \text { addition }[\mathrm{mg}] \\
\text { per fertilization }\end{array}$} \\
\hline & & $\mathrm{NO}_{3}-$ & $\mathrm{NH}_{4}+$ & $\mathrm{NO}_{3}-$ & $\mathrm{NH}_{4}+$ \\
\hline 1 & $1 \times 4: 1$ & 0.8 & 0.2 & 49.6 & 3.6 \\
\hline 2 & $1 \times 1: 4$ & 0.2 & 0.8 & 12.4 & 14.4 \\
\hline 3 & $4 \times 4: 1$ & 3.2 & 0.8 & 198 & 14.4 \\
\hline 4 & $4 \times 1: 4$ & 0.8 & 3.2 & 49.6 & 57.6 \\
\hline
\end{tabular}

simulate a four-fold increase of $\mathrm{N}$ supply. The quantitative effects of $\mathrm{N}$ increase were tested using both natural $\left(1 \mathrm{mM}\right.$ fertilization ${ }^{-1}, 2 \mathrm{mM}$ week $^{-1}$ ) and four-fold $(4 \mathrm{mM}$ fertilization $^{-1}, 8 \mathrm{mM}^{\text {week }}{ }^{-1}$ ) input (Table 1). In order to examine the effects of different $\mathrm{NO}_{3}{ }^{-}: \mathrm{NH}_{4}{ }^{+}$supply ratios, we chose an $\mathrm{NH}_{4}{ }^{+}$-excess supply ratio of $1: 4 \mathrm{NO}_{3}{ }^{-}: \mathrm{NH}_{4}{ }^{+}$ based on future projection figures (Ciais et al. 2013) and a $\mathrm{NO}_{3}{ }^{-}$-excess supply ratio of $4: 1 \mathrm{NO}_{3}{ }^{-}: \mathrm{NH}_{4}{ }^{+}$to simulate the original lake water. The $2 \times 2$ factorial design resulted in four treatments with two $\mathrm{N}$ supply quantities $(1$ and $4 \mathrm{mM})$ and two $\mathrm{N}$ supply ratios $\left(4: 1\right.$ and $\left.1: 4 \mathrm{NO}_{3}^{-}: \mathrm{NH}_{4}^{+}\right)$of $\mathrm{N}$ (Table 1$)$, with treatment $1(1 \times 4: 1)$ being the closest approximation to natural conditions. The experimental design also provided three different supply levels of $\mathrm{NO}_{3}{ }^{-}$and $\mathrm{NH}_{4}{ }^{+}(0.2,0.8$ and $3.2 \mathrm{mM}_{\text {fertilization }}^{-1}$; Table 1).

The $\mathrm{N}$ addition was performed twice weekly (Mondays and Thursdays) over the entire experimental period in order to simulate semi-continuous fertilization. The fertilization solutions for each mesocosm were freshly prepared in the laboratory prior to fertilization, using sodium nitrate $\left(\mathrm{NaNO}_{3}\right)$ and ammonium chloride $\left(\mathrm{NH}_{4} \mathrm{Cl}\right)$ as $\mathrm{N}$ sources. The stock solutions for the $4: 1$ and 1:4 $\mathrm{NO}_{3}{ }^{-}: \mathrm{NH}_{4}{ }^{+}$treatments contained: (I) $0.32 \mathrm{mM} \mathrm{NaNO}_{3}+0.08 \mathrm{mM} \mathrm{NH}_{4} \mathrm{Cl}$ and (II) $0.08 \mathrm{mM} \mathrm{NaNO}_{3}+0.32 \mathrm{mM} \mathrm{NH}_{4} \mathrm{Cl}$. Depending on the treatment, 2.5 or $10 \mathrm{~mL}$ of either stock solution I or II was placed into a labeled one-liter bottle, which was subsequently filled up to the mark with distilled water ( $\mathrm{N}$ fertilization scheme, Table 1). The bottles of fertilization solution were subsequently brought to the lake and emptied into the respective enclosures. Immediately afterwards, a Secchi disc was lowered into each enclosure in order to distribute the $\mathrm{N}$ in the water column. To ensure that differences were present early in the experiment, an initial fertilization containing a two-week $\mathrm{N}$ amount (4 fertilizations) was performed on March 13, 2014. The experiment was conducted for a total of 11 weeks, and included 22 fertilizations.

\section{Sampling program and laboratory analysis}

Water samples were taken twice weekly with an integrated water sampler (KC Denmark A/S Research Equipment, Denmark) from a depth of 0.5-2.5 m. For all the following analyses, the water was pre-filtered directly on site using a 250- $\mu \mathrm{m}$ mesh in order to exclude mesozooplankton. The sampling time was kept as short as possible and the samples were stored in coolers for transportation. Within $1.5 \mathrm{~h}$, the samples were in the laboratory's refrigerator $\left(\sim 8{ }^{\circ} \mathrm{C}\right)$, from where they were immediately processed. The chemical parameters of the water in each enclosure were measured weekly.

The nitrate and nitrite concentrations were determined by means of ion chromatography on particle-free water (Dionex ICS-1100 Basic Integrated IC System with Dionex IonPac 
AS22; Thermo Scientific, USA; detection limit $2 \mu \mathrm{M})$. Prior to filtration in the laboratory, the syringe filters $(0.45 \mu \mathrm{m}, \mathrm{CS}$ 400 Syringe Filters Cellulose Acetate Nalgene, USA) were rinsed several times with deionized water. Subsequently, 2 -mL aliquots of enclosure water was filtered and $\sim 1 \mathrm{~mL}$ of the particle-free water was injected into the Dionex $(20 \mu \mathrm{L}$ were sampled for the measurement).

Ammonium was determined using the orthophthalate method on the $250 \mu \mathrm{m}$ pre-filtered water samples, which was modified from Holmes et al. (1999). Immediately after returning to the laboratory, the pre-filtered water samples were processed by mixing a $2.5-\mathrm{mL}$ aliquot of enclosure water with $10 \mathrm{~mL}$ of working reagent (borate buffer, sodium sulfite and orthophthaldialdehyde in ethanol) in a scintillation vial. Following a 2-h dark incubation, the yellowcolored complex was measured in a Trilogy Laboratory Fluorometer (Module CDOM/NH4; Turner Designs, USA).

Soluble reactive $\mathrm{P}(\mathrm{SRP})$ was not measured since previous studies had indicated that it was rarely measurable in Lake Brunnsee, and we therefore focused on total P (TP). $12 \mathrm{~mL}$ of enclosure water was analyzed for TP, using the molybdenum blue reaction following digestion with $0.7 \mathrm{~mL}$ of sulfuric acid. Subsequently, $0.7 \mathrm{~mL}$ of ascorbic acid and $0.7 \mathrm{~mL}$ of a reagent mixture (sulfuric acid, antimony potassium tartrate and ammonium molybdate solution) were added. The blue color complex was measured with a spectrophotometer at $880 \mathrm{~nm}$ after $30 \mathrm{~min}$ (Shimadzu UV-1700, Shimadzu Cooperation, Germany) (Wetzel and Likens 1991).

The particulate organic carbon (POC), particulate nitrogen (PN) and particulate phosphorus (PP) were analyzed in order to determine seston stoichiometry. 200 to $250 \mathrm{~mL}$ of enclosure water was filtered on glass fiber filters once a week (GF/F, $0.7 \mu \mathrm{m}$, precombusted for $4 \mathrm{~h}$ at $500{ }^{\circ} \mathrm{C}$ and washed in $8 \%$ hydrochloric acid prior to use). For the POC measurements, the filters were incubated with phosphoric acid $(0.5 \mathrm{M})$ for $30 \mathrm{~s}$ to evaporate the calcite. All the filters were directly frozen at $-20{ }^{\circ} \mathrm{C}$ until the measurements. As with the TP value, the PP was analyzed using the molybdenum blue reaction after the filter was digested in $12 \mathrm{~mL}$ of distilled water and $0.7 \mathrm{~mL}$ of sulfuric acid (Wetzel and Likens 1991). The POC and PN filters were dried for $24 \mathrm{~h}$ at $60{ }^{\circ} \mathrm{C}$, placed in tin foil and measured with an elemental analyzer (vario MicroCube, Elementar, Germany).

To document phytoplankton development, the chlorophyll $a$ concentrations were measured twice weekly in vivo using spectral fluorometry (AlgaeLabAnalyser, bbe Moldaenke GmbH, Germany). The water samples were kept in darkness until analysis $(\sim 1.5 \mathrm{~h})$ in order to obtain the optimal fluorescence intensity (Maxwell and Johnson 2000). The AlgaeLabAnalyser measures chlorophyll $a$ fluorescence at $685 \mathrm{~nm}$ following the excitation of the photosynthetic pigments by light-emitting diodes at five different wavelengths $(450,525,570,590$ and $610 \mathrm{~nm}$; for a detailed description, see Beutler et al. 2002). In addition to total chlorophyll $a$ concentration, it calculates the abundance of spectrally identified algal groups by fitting their pigment excitation spectra to so-called norm curves (Beutler et al. 2002). The four spectral groups identified are the brown (Heterokontophyta, Dinophyta), green (Chlorophyta), blue (Cyanobacteria) and mixed groups (Cryptophyta; for descriptions and validation of the method, see Beutler et al. 2002).

We followed the calculations of Ptacnik et al. (2008) to compare the resource use efficiency (RUE) of phytoplankton at different $\mathrm{NO}_{3}{ }^{-}: \mathrm{NH}_{4}{ }^{+}$ratios. The RUE for each mesocosm was obtained by dividing the highest chlorophyll $a$ concentration by the highest TP concentration (at the beginning of the experiment; $\left.\mathrm{RUE}_{\mathrm{Chl} a}=\mathrm{Chl} a / \mathrm{TP}\right)$.

To determine the phytoplankton biomass effects and the potential taxonomic shifts in the community, water samples were fixed in Lugol's iodine and the phytoplankton were later counted under an inverted microscope (Wild M40, Germany) following established methods (Uthermöhl 1958). Samples from days 49 to 63 were analyzed, as the in vivo chlorophyll $a$ measurements indicated treatment effects during this time period. To this end, $50 \mathrm{~mL}$ of the fixed water sample was placed in sedimentation chambers and, after settling for $48 \mathrm{~h}, 400$ specimens of the most abundant species were counted in at least two rows. This was done at magnifications of 40 to 400 , depending on algal size. The respective phytoplankton abundances were subsequently calculated as biovolumes by multiplying the cell counts by the species cell volume, which was either obtained through direct measurements (Hillebrand et al. 1999) or from existing data from previous studies on this lake.

The data were statistically analyzed using Systat Software 2008 (Sigma Plot 11.0). On the basis of the experimental design, two-way ANOVAs were performed with fixed factors ( $\mathrm{N}$ amount and $\mathrm{NO}_{3}^{-}: \mathrm{NH}_{4}{ }^{+}$ratio) and the interaction term ( $\mathrm{N}$ amount*ratio). The nutrient data were averaged over the experimental period. The averages for phytoplankton chlorophyll $a$, microscopic biovolume, seston stoichiometry, $\mathrm{RUE}_{\mathrm{Chl} a}$ and chlorophyll $a$ : POC ratio were calculated over days 49 to 63 (maximal phytoplankton abundance). The maximum chlorophyll $a$ concentrations were tested separately.

\section{Results}

\section{Nitrogen dynamics}

Significant differences in the amount of dissolved N compounds $\left(\mathrm{NH}_{4}{ }^{+}\right.$and $\left.\mathrm{NO}_{3}{ }^{-}\right)$were established between the treatments (averages over time: $\mathrm{NH}_{4}{ }^{+}$: interaction term $p<0.001 ; \mathrm{NO}_{3}{ }^{-}$: interaction term $\left.p<0.001\right)$. The temperature in the enclosures increased from $\sim 7.4( \pm 0.1$ st.dev. $)$ to 
a maximum of $19.5( \pm 0.1){ }^{\circ} \mathrm{C}$. The average light attenuation coefficient on day 23 was $0.83( \pm 0.12)$, which was equivalent to a $10-\mathrm{m}$ euphotic zone in the lake. No differences in the mean temperature and light attenuation coefficient were observed between the treatments on day 23 (averages over time: temperature: $p>0.05$; light: $p>0.05$ Kruskal-Wallis-test).

While the $\mathrm{NH}_{4}{ }^{+}$concentration increased following the initial fertilization, it remained below $2.3 \mu \mathrm{M}$ in treatment 1 , and within a slightly unimodal range from 1.2 to $6.6 \mu \mathrm{M}$ in treatments 2 and 3 (Fig. 1a); only treatment 4 obtained an increase of up to $28.3 \mu \mathrm{M}$ (Fig. 1a). In the first 15 days after the start of the experiment, the $\mathrm{NO}_{3}{ }^{-}$concentration fell from $344 \mu \mathrm{M}$ by $10 \mu \mathrm{M}$ (treatment 3) to $24 \mu \mathrm{M}$ (treatments 1, 2 and 4) (Fig. 1b). Following this period, it rose
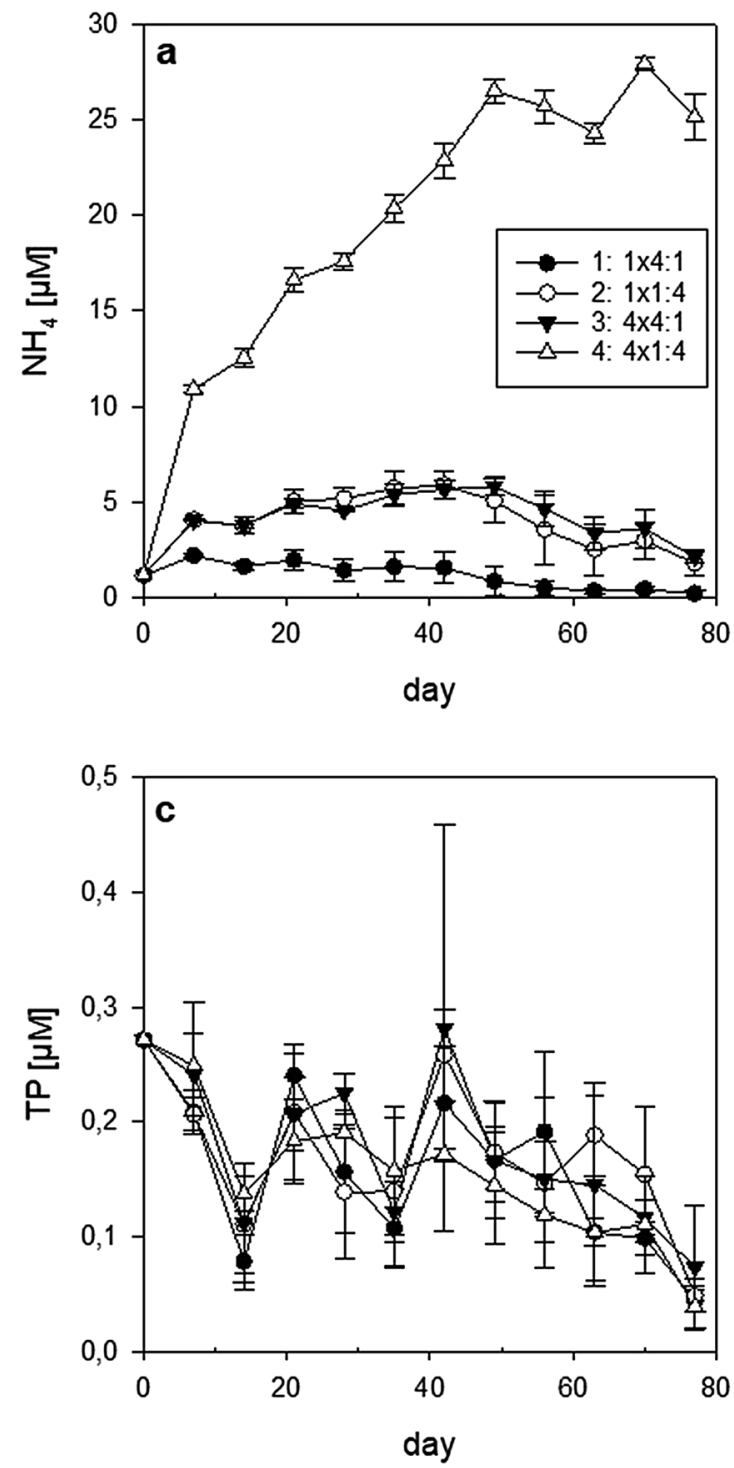

to $358 \mu \mathrm{M}$ in treatment 3 , and hovered around $326( \pm 3.4)$ $\mu \mathrm{M}$ in treatments 1,2 and 4 (Fig. 1b). Meanwhile, the TP concentrations decreased from 0.27 to $\sim 0.05 \mu \mathrm{M}$ and averaged around $0.16 \mu \mathrm{M}$ (Fig. 1c), with no statistical differences noted between the treatments with regard to TP $(p>0.05)$.

Despite continuous $\mathrm{N}$ fertilization, the $\mathrm{NO}_{3}{ }^{-}$and $\mathrm{NH}_{4}{ }^{+}$ concentrations observed at the end of the experiment were below the theoretical endpoints (starting concentration plus all $\mathrm{N}$ additions, excluding any turnover) in all the enclosures (except for $\mathrm{NO}_{3}{ }^{-}$in No. 11; see Fig. 2a, b). From the amount of $\mathrm{N}$ missing from each mesocosm at the end of the experiment, we estimate a net $\mathrm{N}$ removal of $3-19 \mu \mathrm{M}$ in $\mathrm{NH}_{4}^{+}$and -0.7 to $20 \mu \mathrm{M}$ in $\mathrm{NO}_{3}^{-}$(Fig. 2c, d), indicating mainly a phytoplankton uptake and a microbial turnover. The $\mathrm{NH}_{4}{ }^{+}$removal increased with greater $\mathrm{NH}_{4}{ }^{+}$addition

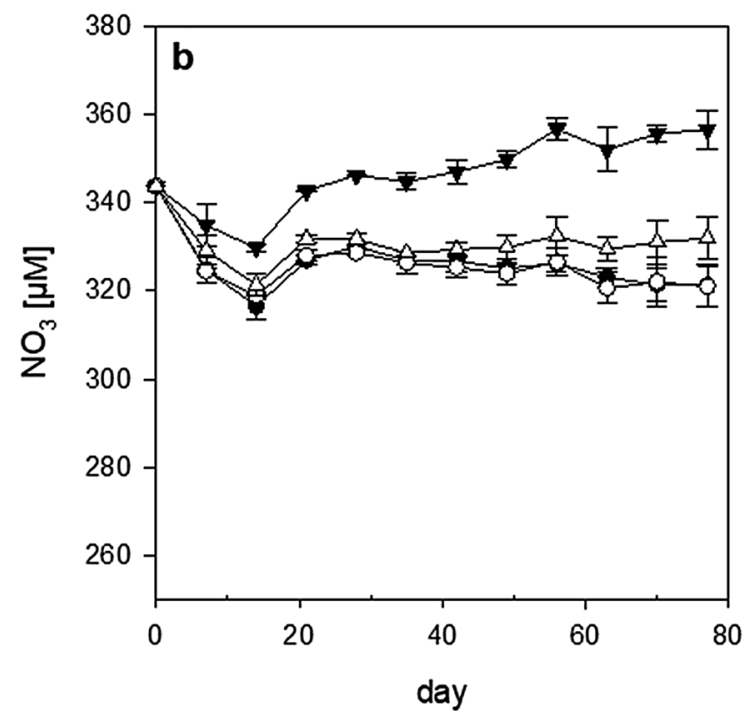

Fig. 1 Nutrient concentrations of $\mathbf{a ~} \mathrm{NH}_{4}{ }^{+}, \mathbf{b ~ N \mathrm { NO } _ { 3 }}{ }^{-}$and $\mathbf{c} \mathrm{TP}(\mu \mathrm{M})$ are shown as averages of three replicates per treatment. The error bars represent standard deviation 
(Fig. 2d, $R^{2}=0.95, p<0.05$ ), but not with an increase in $\mathrm{NO}_{3}{ }^{-}(p>0.05)$. The removal of $\mathrm{NO}_{3}{ }^{-}$did not correlate with $\mathrm{NO}_{3}{ }^{-}$addition (Fig. $2 \mathrm{c}, p>0.05$ ), but it decreased with increasing $\mathrm{NH}_{4}{ }^{+}$addition $\left(R^{2}=0.34, p<0.05\right)$.

\section{Stoichiometric responses}

The seston stoichiometry data over the experimental period indicated $\mathrm{P}$ limitation. The seston $\mathrm{C}: \mathrm{P}$ ratios increased from 252 at the beginning of the experiment to $634( \pm 106)$ at the end, with an average of $498( \pm 182)$. The seston N:P ratios averaged $83( \pm 28)$, and rose from an initial value of 42 to a final value of $101( \pm 23)$. The seston $\mathrm{C}: \mathrm{N}$ ratios fluctuated between 3.1 and 9.1 (average $6.1 \pm 1.3$ ). No significant differences were observed for any of the stoichiometric ratios between the treatments over the chlorophyll $a$ peak $(p>0.05)$. Lower seston $\mathrm{C}: \mathrm{N}$ ratios were only observed in the fourfold $\mathrm{N}$ treatments on day 49 ( $\mathrm{N}$ amount $p<0.05$ ). On days 49 to 63 , higher chlorophyll $a$-to-POC ratios were observed in the $\mathrm{NH}_{4}{ }^{+}$-excess treatment $\left(\mathrm{NO}_{3}{ }^{-}: \mathrm{NH}_{4}{ }^{+}\right.$ratio $1: 4$; $\mathrm{N}$ ratio $p<0.05)$, indicating more chlorophyll $a$ production per unit particular organic carbon as a proxy for algae biomass.

\section{Phytoplankton development and resource use efficiency}

The total chlorophyll $a$ concentrations reached maximum values of 2 to $6 \mu \mathrm{g} \mathrm{L}^{-1}$ in early May, from days 49 to 59 of the experiment (Fig. 3a). During this period, the brown spectral group contributed $>85 \%$ of the total, followed by the green group (Fig. 3b, c). In the first month of the experiment, however, the mixed group also displayed a bloom, with a maximum chlorophyll $a$ value of $1 \mu \mathrm{g} \mathrm{L}^{-1}$ (Fig. 3d). By contrast, the blue spectral group only occasionally reached 0.01 to $0.04 \mu \mathrm{g} \mathrm{L}{ }^{-1}$ (not shown). Significant differences in total chlorophyll $a$ were observed for the applied $\mathrm{N}$ ratio treatments at maximum chlorophyll $a$ concentrations
Fig. 2 The observed versus the predicted end concentrations of $\mathbf{a ~ N O}{ }_{3}^{-}$and $\mathbf{b ~ N H _ { 4 }}{ }^{+}$ (solid line equates $R^{2}=1$ ), and the removed versus the predicted end concentrations of $\mathbf{c} \mathrm{NO}_{3}^{-}\left(R^{2}=0.01 ; p>0.05\right)$ and $\mathbf{d ~} \mathrm{NH}_{4}^{+}(y=0.41 x+3.4$, $\left.R^{2}=0.95, p<0.001\right)$. Predicted end concentrations are the theoretical endpoints of the starting concentrations plus all the $\mathrm{N}$ additions, excluding any turnover. The removed amount is the difference between the predicted and the observed end concentrations
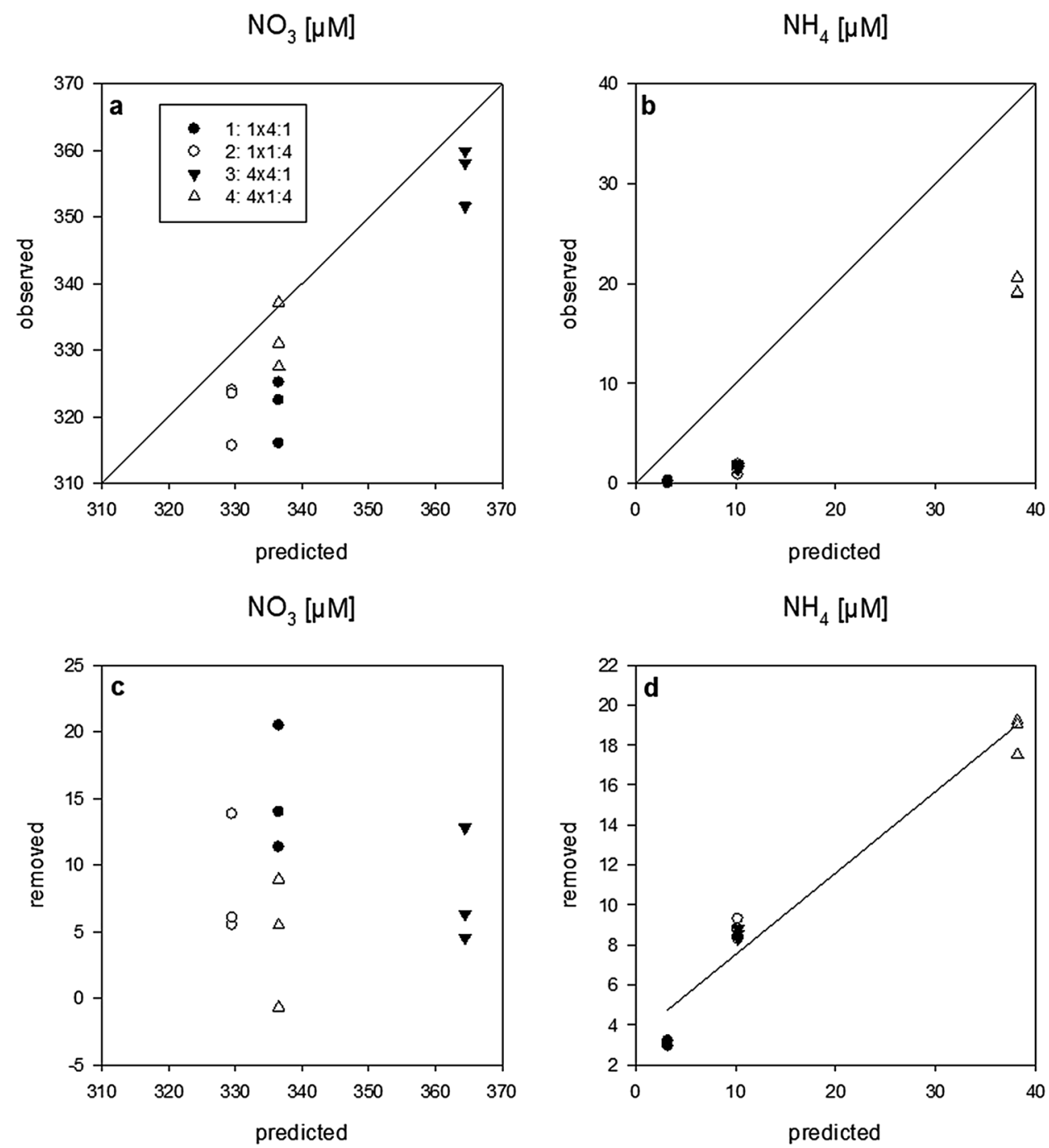
(Fig. 4, Table 2), as well as for the green and brown spectral groups (Table 2). In all the cases, the $\mathrm{NH}_{4}{ }^{+}$-excess treatment $\left(\mathrm{NO}_{3}{ }^{-}: \mathrm{NH}_{4}{ }^{+}\right.$ratio 1:4) led to significantly higher chlorophyll $a$ concentrations (Tukey Test $\mathrm{N}$ ratio $p<0.05$, repeated measures ANOVA $N$ ratio $p<0.05$ ). No clear differences were noted between the $\mathrm{N}$ ratios for the mixed group during this time (Table 2), but they appeared earlier at their peak abundance on day 21 ( $\mathrm{N}$ ratio $p<0.05$ ). In addition, the $\mathrm{RUE}_{\mathrm{Chl} a}$ of the phytoplankton communities were significantly higher for both $1: 4 \mathrm{NO}_{3}{ }^{-}: \mathrm{NH}_{4}{ }^{+}$treatments $(\mathrm{N}$ ratio $p<0.01$ ) than they were for the $4: 1 \mathrm{NO}_{3}{ }^{-}: \mathrm{NH}_{4}{ }^{+}$cases (Fig. 5), indicating greater biomass yield with a higher $\mathrm{NH}_{4}^{+}$ supply.

\section{Phytoplankton community composition}

The phytoplankton biovolume calculated by means of microscopic counting was highest on days 49 and 59, reaching between $4.92 \times 10^{8}$ and $1.79 \times 10^{9} \mu \mathrm{m}^{3} \mathrm{~L}^{-1}$ in the enclosures. We observed mean treatment differences for total phytoplankton biovolume on the basis of the $\mathrm{N}$ ratio applied (Fig. 6 a, Table 3, Tukey Test $\mathrm{N}$ ratio $p<0.05$, repeated measures ANOVA $\mathrm{N}$ amount and $\mathrm{N}$ ratio $p<0.05)$. These differences were mainly due to green algae, which proliferated in the $\mathrm{NH}_{4}{ }^{+}$-excess treatments $\left(\mathrm{NO}_{3}{ }^{-}: \mathrm{NH}_{4}{ }^{+}\right.$ratio $\left.1: 4\right)$ (Fig. 6b). This was most prominently seen in the genus Chlamydomonas sp. ( $\mathrm{N}$ ratio $p<0.05)$. Green algae comprised the largest proportion of total phytoplankton biovolume, with an average of $\sim 67 \%$, followed by diatoms $(\sim 29 \%)$ and other taxonomical groups (dinoflagellates $\sim 2 \%$, cryptophytes $\sim 1 \%$, cyanobacteria $\sim 1 \%$ and chrysophytes $<1 \%$, Fig. 6b). The community was dominated by Chlamydomonas sp. $(\sim 65 \%)$ and Cyclotella sp. ( 26\%). Ceratium hirudinella, Fragilaria sp., Asterionella sp., Crucigenia sp. and Rhodomonas sp. accounted for only $\sim 1$ to $2 \%$ of the total biovolume, while Dinobryon sp. and Anabaena sp. made up $<1 \%$. No effects of the $\mathrm{N}$ fertilization applied were observed on the biovolumes of the diatoms, dinoflagellates, chrysophytes and cryptophytes (Table 3). The mean biovolume of the cyanobacteria during the peak phase was positively affected by the $\mathrm{N}$ amount supplied (Table 3 ).
Fig. 3 Chlorophyll $a$ development over the experimental period: concentrations of total chlorophyll $a$ and the chlorophyll $a$ of the brown, green and mixed spectral algal groups. The averages of three replicates per treatment are shown. The error bars represent standard deviation
Total chlorophyll a

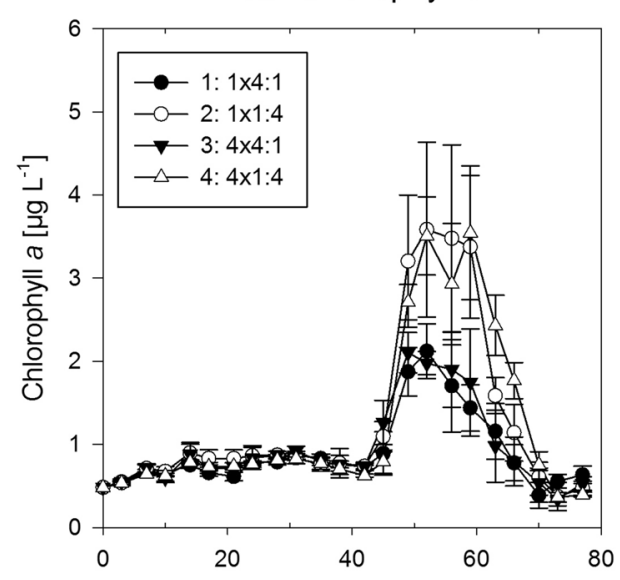

green

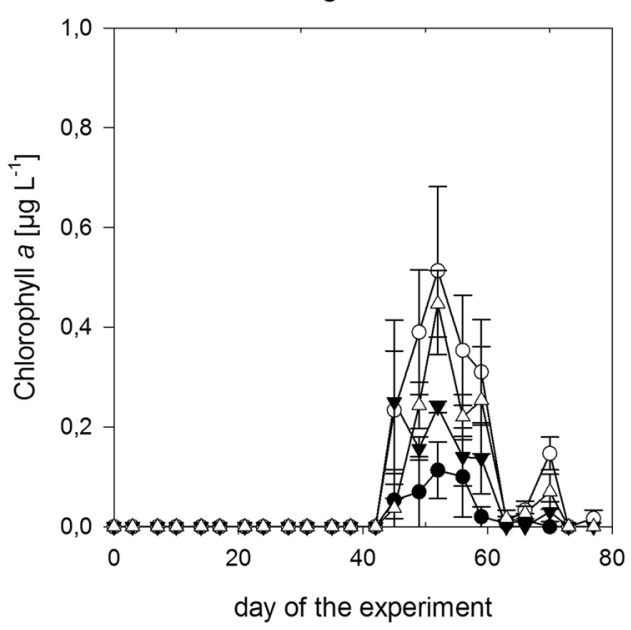

brown

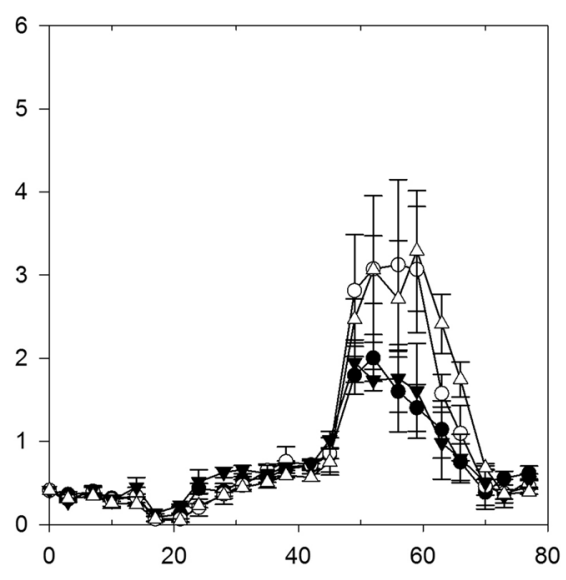

mixed

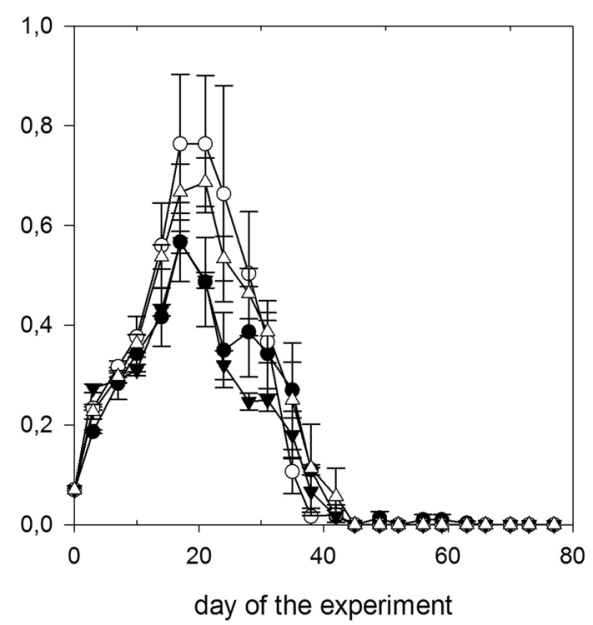




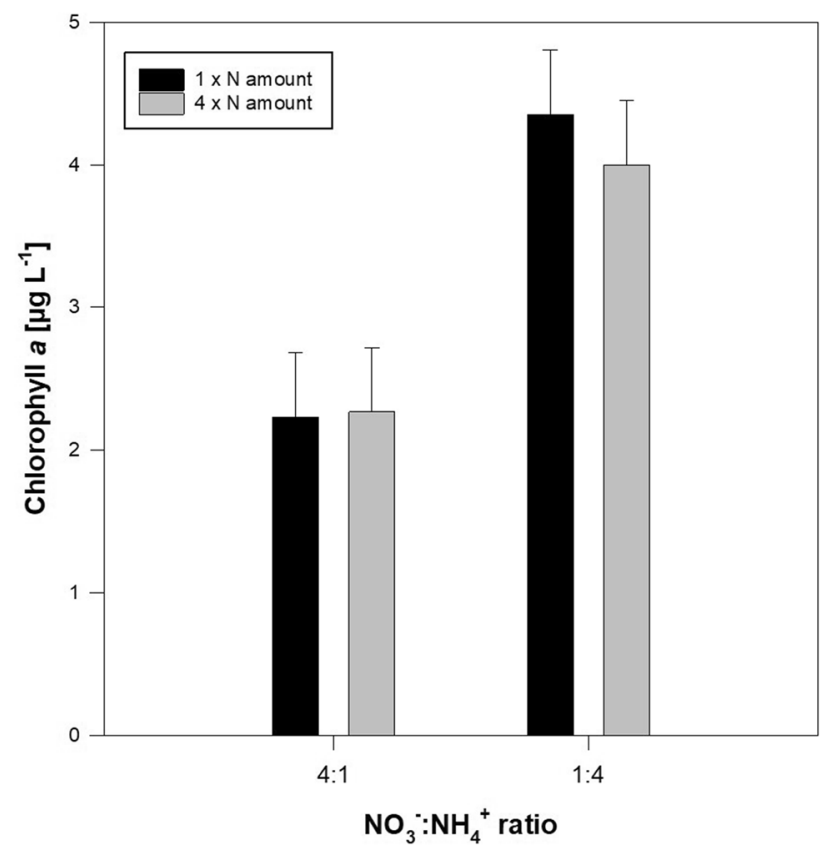

Fig. 4 Bar plot of maximum chlorophyll $a$ concentrations $\left(\mu \mathrm{g} \mathrm{L}^{-1}\right)$ versus $\mathrm{NO}_{3}^{-}: \mathrm{NH}_{4}^{+}$treatments (4:1 and 1:4). The averages of three replicates per treatment are shown. The error bars represent standard deviation. Black bars (1): natural deposition, grey bars (4): four-fold natural deposition. $\mathrm{NO}_{3}{ }^{-}: \mathrm{NH}_{4}{ }^{+}$ratio: $p<0.01$

Table 2 Two way ANOVA results for chlorophyll $a$, with total $\mathrm{N}$ amount and $\mathrm{NO}_{3}^{-}: \mathrm{NH}_{4}{ }^{+}$supply ratios as fixed factors

\begin{tabular}{llllll}
\hline & Total chl $a$ & Green & Brown & Blue & Mixed \\
\hline Amount & 0.73 & 0.85 & 0.79 & 0.87 & 0.76 \\
Ratio & $\mathbf{0 . 0 0 3}$ & $\mathbf{0 . 0 2}$ & $\mathbf{0 . 0 0 4}$ & 0.43 & $\mathbf{0 . 1 0}$ \\
Amount $\times$ ratio & 0.68 & 0.22 & 0.815 & 0.43 & 0.65 \\
\hline
\end{tabular}

The $p$-values are shown for maximum concentrations of total chlorophyll $a$, and the respective concentrations of green, brown, blue and mixed spectral algal groups. Bold: $p<0.05$, italic $0.05<p \leq 0.1$

\section{Discussion}

We investigated the effects of $\mathrm{N}$ enrichment on phytoplankton dynamics in a primarily P-limited, oligotrophic lake, using different $\mathrm{N}$ source ratios $\left(\mathrm{NO}_{3}{ }^{-}, \mathrm{NH}_{4}{ }^{+}\right)$. The factorial experimental design applied had two $\mathrm{N}$ supply quantities and two $\mathrm{NO}_{3}{ }^{-}: \mathrm{NH}_{4}{ }^{+}$supply ratios, and revealed clear effects of the supplied $\mathrm{NO}_{3}{ }^{-}: \mathrm{NH}_{4}{ }^{+}$ratios on several aspects of the phytoplankton community. Until now, phytoplankton responses to $\mathrm{NO}_{3}{ }^{-}$and $\mathrm{NH}_{4}{ }^{+}$have been mainly investigated in N-limited systems (Bergström and Jansson 2006; Duce et al. 2008; Donald et al. 2013). Lake Brunnsee, with $\mathrm{TP}<0.3 \mu \mathrm{M}$ and dissolved molar $\mathrm{N}: \mathrm{P}$ ratios of $>1000: 1$ (after winter mixing) indicating a severe scarcity of $\mathrm{P}$, demonstrated a significantly higher phytoplankton biomass in treatments with greater $\mathrm{NH}_{4}{ }^{+}$ fertilization (Tables 2 and 3, Fig. 4). This clearly suggests enhanced growth conditions for specific algal groups under higher $\mathrm{NH}_{4}{ }^{+}$supply, which were evidenced by the chlorophyll $a$ concentrations measured, the microscopically determined total phytoplankton biovolume and phytoplankton resource use efficiency, indicated by the amount of chlorophyll $a$ per TP unit (Ptacnik et al. 2008).

With respect to the first hypothesis of this study, the $\mathrm{N}$ amount supplied did not affect the total phytoplankton biomass (Tables 2 and 3). The maximum phytoplankton biomass was achieved in treatments with 1:4 $\mathrm{NO}_{3}^{-}: \mathrm{NH}_{4}{ }^{+}$ supply ratios. If absolute $\mathrm{NH}_{4}{ }^{+}$availability had limited phytoplankton production in the lake investigated, the greatest phytoplankton biomass development would have been expected with the highest $\mathrm{NH}_{4}{ }^{+}$supply $\left(4 \times 1: 4 \mathrm{NO}_{3}{ }^{-}: \mathrm{NH}_{4}{ }^{+}\right.$ ratio treatment, $\mathrm{N}$ fertilization per week: $6.4 \mathrm{mM}$ enclosure ${ }^{-1}$ or $2.9 \mu \mathrm{M}$ ), which was not the case. This observation might potentially be due to the growth inhibition of phytoplankton under high $\mathrm{NH}_{4}{ }^{+}$conditions, which was already observed at $\mathrm{NH}_{4}{ }^{+}$concentrations of about $10-100 \mu \mathrm{M}$ (Yoshiyama and Sharp 2006; Dugdale et al. 2012; Glibert et al. 2016). In addition, a saturation effect related to the amount of available $\mathrm{P}$ could have limited the maximum biomass production at the highest $\mathrm{NH}_{4}{ }^{+}$levels (Yoshiyama and Sharp 2006). At the given TP of $<0.3 \mu \mathrm{M}$, chlorophyll $a$ concentrations of 4-7 $\mu \mathrm{g} \mathrm{L}^{-1}$ appear to be the upper range of attainable phytoplankton biomass (Fig. 2B in Ptacnik et al. 2008). In terms of $\mathrm{N}$ budgets, the absolute amounts of $\mathrm{N}$ removed from the dissolved phase were of similar magnitude for $\mathrm{NH}_{4}{ }^{+}$and $\mathrm{NO}_{3}{ }^{-}$(Fig. 2c, d). The same $\mathrm{NH}_{4}{ }^{+}$amount was added for the $1 \times 1: 4$ and $4 \times 4: 1 \mathrm{NO}_{3}^{-}: \mathrm{NH}_{4}{ }^{+}$ratio treatments (Table 1 , Fig. 1a) and approximately the same amount was removed (Fig. 2d). Nevertheless, the greater biomass was observed in the elevated $\mathrm{NH}_{4}{ }^{+}$treatments $\left(\mathrm{NO}_{3}{ }^{-}: \mathrm{NH}_{4}{ }^{+}\right.$ratio 1:4). These results clearly suggest $\mathrm{NH}_{4}{ }^{+}$as the preferred growth- and biomass-promoting $\mathrm{N}$ source for the algae community in our experiment. Similar effects of significantly higher phytoplankton biomass with $\mathrm{NH}_{4}{ }^{+}$rather than $\mathrm{NO}_{3}{ }^{-}$fertilization have been noted for cyanobacteria and chlorophytes (McCarthy et al. 2009; Domingues et al. 2011; Donald et al. 2011, 2013; Glibert et al. 2016 and references therein).

We observed that $\mathrm{NH}_{4}{ }^{+}$removal from the dissolved phase increased with greater $\mathrm{NH}_{4}{ }^{+}$supply (Fig. 2), although the reported nutrient concentrations may not fully reflect the in situ concentrations due to the continued activity of microbial processes within the sample bottle between water sample collection and processing. This removal includes not only algal $\mathrm{N}$ uptake, but also potential uptake and conversion by bacteria and abiotic transformations. The control measurements showed that the mesocosms were oxygenated over the entire depth $\left(\sim 10.5 \pm 2.5 \mathrm{mg} \mathrm{L}^{-1}\right)$ and that the $\mathrm{pH}$ was slightly alkaline (third week of the experiment $\sim 7.2 \pm 0.1$, 
Fig. 5 Bar plot of the total $\mathrm{RUE}_{\mathrm{Chl}}$ a at maximum chlorophyll $a$ concentrations versus $\mathrm{NO}_{3}{ }^{-}: \mathrm{NH}_{4}{ }^{+}$treatments $(4: 1$ and 1:4). The averages of three replicates per treatment are shown. The error bars represent standard deviation. Black bars (1): natural deposition, grey bars (4): four-fold natural deposition. $\mathrm{NO}_{3}^{-}: \mathrm{NH}_{4}{ }^{+}$ratio: $p<0.01$

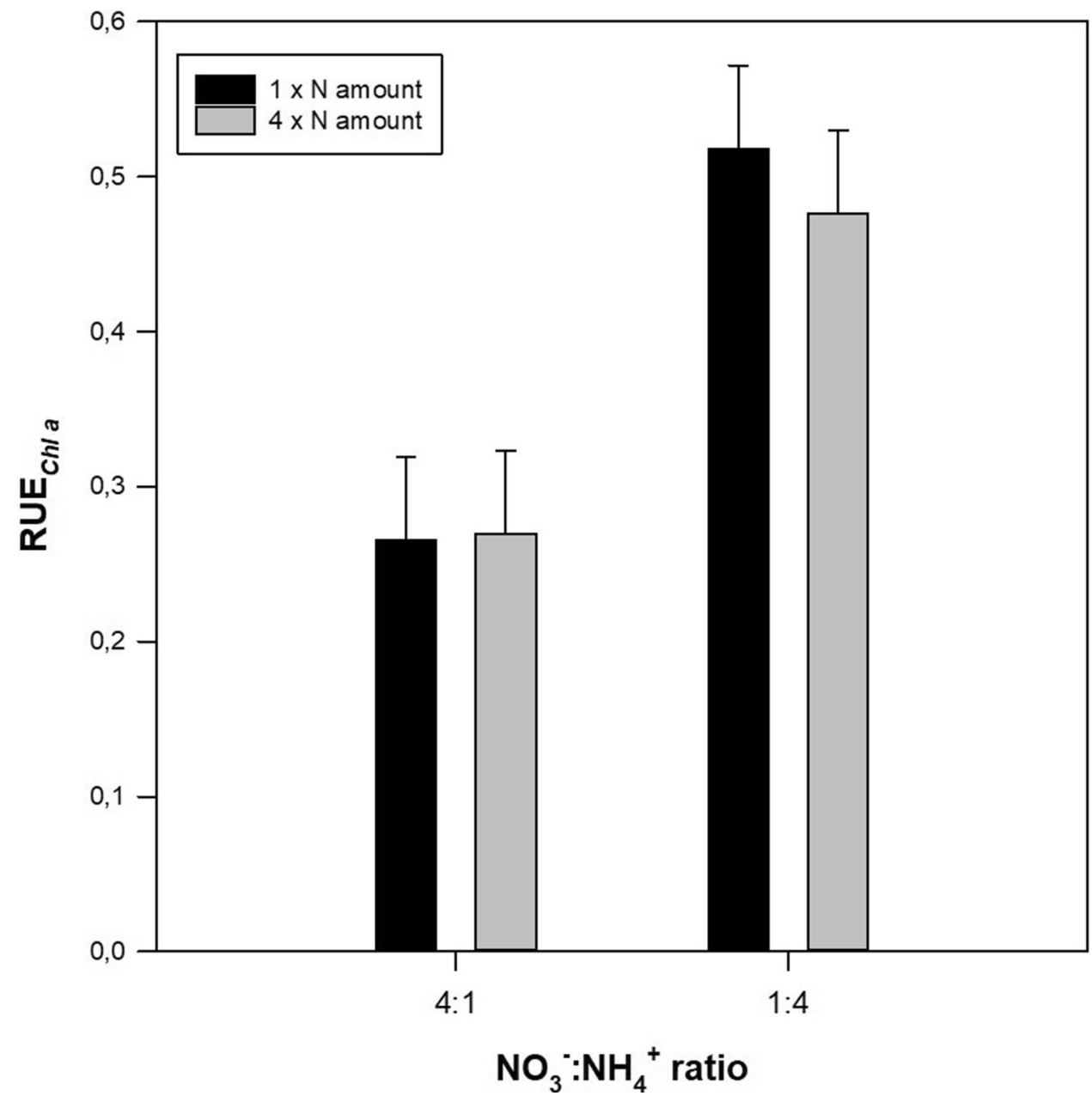

last week of the experiment $\sim 8.1 \pm 0.1$ ). Under these circumstances, considerable effects of $\mathrm{NH}_{3}$ volatilization or denitrification were not expected. Phytoplankton are known to prefer the energetically favorable $\mathrm{NH}_{4}{ }^{+}$. Therefore, a high $\mathrm{NH}_{4}{ }^{+}$ supply may be beneficial to certain phytoplankton taxa, but it can also inhibit $\mathrm{NO}_{3}{ }^{-}$uptake for other taxa, such as large diatoms, which prefer to use the latter compound (Eppley et al. 1969b; Sommer 1993; Glibert et al. 2016). Laboratory studies have revealed that $\mathrm{NO}_{3}{ }^{-}$uptake by algae can be efficiently suppressed with $\mathrm{NH}_{4}{ }^{+}$(Eppley et al. 1969a; Cochlan et al. 1991; Hii et al. 2011) through reducing nitrate reductase activity (Lomas 2004; Song and Ward 2004). The inhibition of $\mathrm{NO}_{3}{ }^{-}$uptake reportedly starts at critical $\mathrm{NH}_{4}{ }^{+}$ concentrations of 1 to $15 \mu \mathrm{M}$, depending on the algal species and the total N levels (Dortch 1990; Glibert et al. 2016). In our experiment, the highest concentrations of $>10 \mu \mathrm{M}$ $\mathrm{NH}_{4}{ }^{+}$occurred in treatment $4(4 \times 1: 4)$, and we can only speculate about the relative importance of $\mathrm{NH}_{4}{ }^{+}$inhibition for $\mathrm{NO}_{3}{ }^{-}$uptake. However, whereas our data do not indicate significant differences in $\mathrm{NO}_{3}{ }^{-}$uptake between the fertilization treatments, it appears that $\mathrm{NH}_{4}{ }^{+}$uptake increased with $\mathrm{NH}_{4}{ }^{+}$addition, resulting in a higher phytoplankton biomass.
We therefore assume that the preferential uptake of $\mathrm{NH}_{4}{ }^{+}$, rather than inhibiting the $\mathrm{NO}_{3}{ }^{-}$uptake by $\mathrm{NH}_{4}{ }^{+}$, affected the $\mathrm{N}$ dynamics in our experiment.

The results of the microscopic analyses indicate that it was specifically smaller algae, such as Chlamydomonas sp., that were positively affected by increased $\mathrm{NH}_{4}{ }^{+}$availability, which supports our second hypothesis. This hypothesis is further supported by the chlorophyll $a$ data of the mixed spectral algae group (Fig. 3d), which represent mainly small cryptophytes (Beutler et al. 2002). Small algae have high surface area-to-volume ratios, resulting in greater specific uptake and growth rates when nutrients are scarce. This was demonstrated by the uptake of P (Smith and Kalff 1982), $\mathrm{NO}_{3}{ }^{-}$and $\mathrm{NH}_{4}{ }^{+}$(Eppley et al. 1969b; Dortch 1990; Hein et al. 1995). A marine study has indicated that picoplankton prefer $\mathrm{NH}_{4}{ }^{+}$over $\mathrm{NO}_{3}{ }^{-}$, whereas larger net plankton (15-200 $\mu \mathrm{m}$ ) display no preference for either source (Wafar et al. 2004). Our results support the findings that smaller algae appear to be more competitive under high dissolved $\mathrm{N}: \mathrm{P}$ ratios than larger ones (Edwards et al. 2011). Moreover, they align with predictions that a shift to a higher availability of $\mathrm{NH}_{4}{ }^{+}$in comparison to $\mathrm{NO}_{3}{ }^{-}$may favor small species 

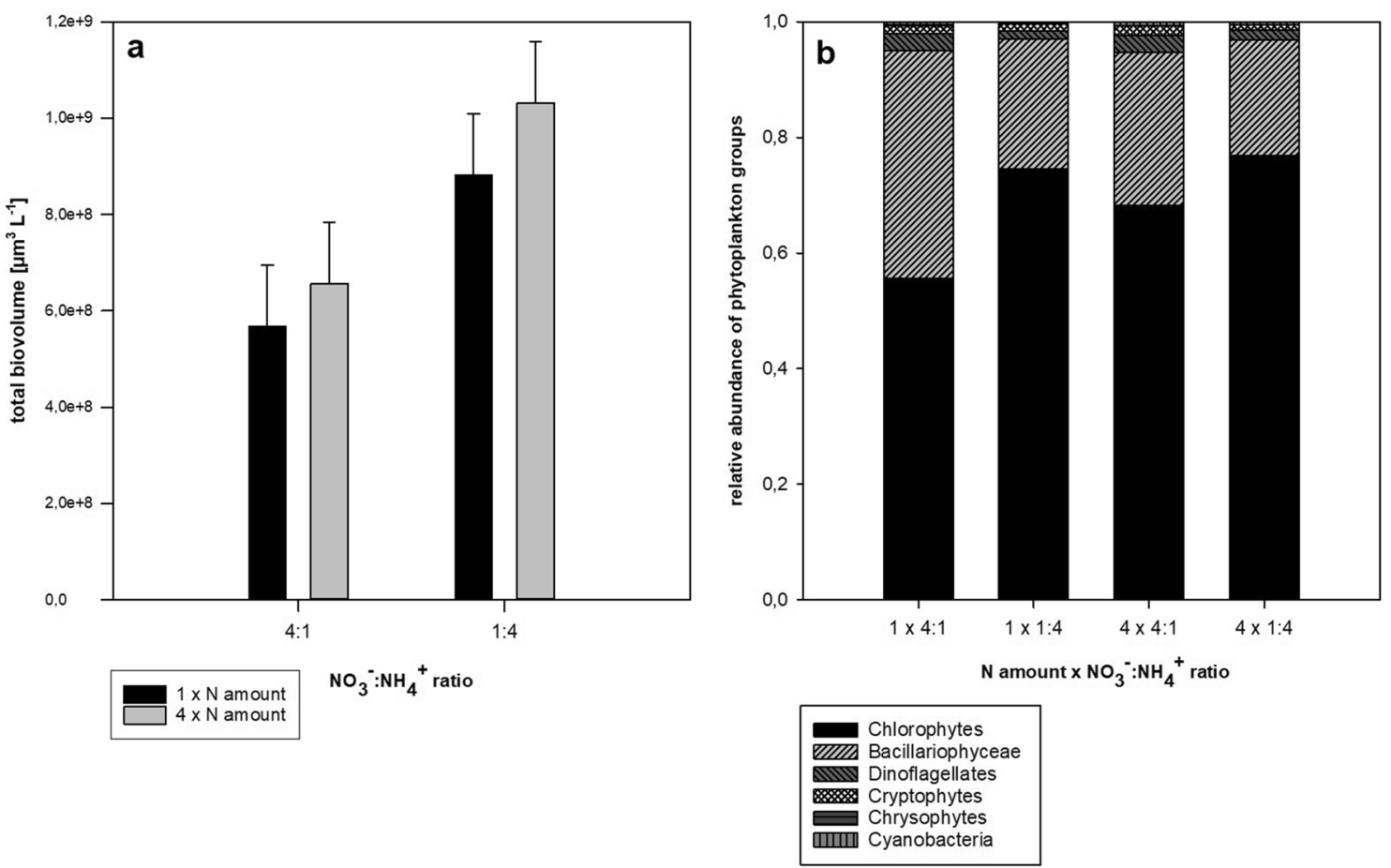

Fig. 6 a Grouped bar chart of average total phytoplankton biovolume $\left[\mu \mathrm{m}^{3} \mathrm{~L}^{-1}\right]$ (days 49-63) versus $\mathrm{NO}_{3}^{-}: \mathrm{NH}_{4}^{+}$treatments (4:1 and 1:4). The averages of three replicates per treatment are shown. The error bars represent standard deviation. Black bars (1): natural deposition,

grey bars (4): four-fold natural deposition. $\mathrm{NO}_{3}{ }^{-}: \mathrm{NH}_{4}{ }^{+}$ratio: $p<0.05$ and $\mathbf{b}$ stacked bar chart of the relative abundance of the phytoplankton groups versus the $\mathrm{N}$ treatments $\left(\mathrm{N}\right.$ amount $\times \mathrm{NO}_{3}{ }^{-}: \mathrm{NH}_{4}{ }^{+}$ratio)

Table 3 Two way ANOVA results for microscopic biovolume, with total $\mathrm{N}$ amount and $\mathrm{NO}_{3}^{-}: \mathrm{NH}_{4}{ }^{+}$supply ratios as fixed factors

\begin{tabular}{llllllll}
\hline & Total biovolume & $\begin{array}{l}\text { Bacillario- } \\
\text { phyceae }\end{array}$ & Chrysophytes & Dinoflagellates & Chlorophytes & Cryptophytes & Cyanobacteria \\
\hline Amount & 0.38 & 0.75 & 0.32 & 0.31 & 0.30 & 0.71 & $\mathbf{0 . 0 1}$ \\
Ratio & $\mathbf{0 . 0 3}$ & 0.95 & 0.61 & 0.40 & $\mathbf{0 . 0 2}$ & 0.57 & 0.86 \\
Amount $\times$ ratio & 0.82 & 0.66 & 0.16 & 0.84 & 1.00 & 0.50 & 0.37 \\
\hline
\end{tabular}

The $p$-values are shown for the phytoplankton biovolumes, averaged over the chlorophyll $a$ peak phase (days 49—63). Bold: $p<0.05$

(Glibert et al. 2016). Their higher nutrient uptake rates and growth under low $\mathrm{P}$ (Smith and Kalff 1982) and $\mathrm{NH}_{4}{ }^{+}$concentrations (Hein et al. 1995) mean that even slight $\mathrm{NH}_{4}{ }^{+}$ additions appear to be sufficient to promote the growth of small algae, which was observed in our field experiment. Our results indicate that the energetics of $\mathrm{N}$ assimilation lead to a preference for $\mathrm{NH}_{4}{ }^{+}$as a nitrogen source, regardless of any nutrient deficiency (Syrett 1981; Dortch 1990).

The examination of the phytoplankton community composition revealed greater proportions of green algae with higher $\mathrm{NH}_{4}{ }^{+}$availability $\left(\mathrm{NO}_{3}{ }^{-}: \mathrm{NH}_{4}{ }^{+}\right.$ratio 1:4; Tables 2 and 3 ). The most abundant algae in our experiment was the green algae flagellate Chlamydomonas sp. Averaging 67\% of the algae biomass, its response to $\mathrm{N}$ enrichment (higher biovolumes in the $\mathrm{NH}_{4}{ }^{+}$-excess treatments) was most probably also the main driver of the response we observed (Table 3). These data agree with earlier findings that green algaeespecially flagellated species-have higher uptake affinities and growth rates with $\mathrm{NH}_{4}{ }^{+}$as a source (Dortch 1990; Raven et al. 1992; Litchman et al. 2007), and therefore profit from a high supply thereof (Domingues et al. 2011). Sommer's (1993) seasonal study of Lake Plußsee also noted the clear effects of $\mathrm{NH}_{4}{ }^{+}$on phytoplankton species in a P-limited system. In addition, he observed a positive correlation between the abundance of three green algae species and decreasing $\mathrm{NO}_{3}{ }^{-}: \mathrm{NH}_{4}{ }^{+}$ratios, as did our experiment. However, it is difficult to clearly link the recorded changes to a single factor in observational field studies. Therefore, our manipulation of $\mathrm{NH}_{4}{ }^{+}$and $\mathrm{NO}_{3}{ }^{-}$supply ratios, while keeping other conditions constant, demonstrates a more causal relationship 
between varying $\mathrm{NO}_{3}^{-}: \mathrm{NH}_{4}{ }^{+}$ratios and the observed responses of phytoplankton species.

Our data also support the third hypothesis that high $\mathrm{NH}_{4}{ }^{+}$ supply ratios increase the RUE of phytoplankton. Notably, the phytoplankton RUE was higher when relatively more $\mathrm{NH}_{4}{ }^{+}$was supplied (under otherwise identical resource conditions; see Fig. 5). This result strongly suggests that the ratio between two available $\mathrm{N}$ sources can affect the transformation efficiency of available $\mathrm{P}$ into new biomass, and that the limiting nutrient $\mathrm{P}$ could be used more readily with $\mathrm{NH}_{4}{ }^{+}$ as the complementary $\mathrm{N}$ source. A previous study of optimal macro- and micronutrient conditions for several algal species observed a similar pattern (Radzun et al. 2015), with $\mathrm{NH}_{4}^{+}$ resulting in higher growth than comparable $\mathrm{NO}_{3}{ }^{-}$concentrations for most of the species. In addition, $\mathrm{P}$ was converted more efficiently into new biomass in the presence of $\mathrm{NH}_{4}{ }^{+}$ instead of $\mathrm{NO}_{3}^{-}$.

\section{Conclusion}

Our data suggest that nitrogen enrichment also affects phytoplankton dynamics in lakes with a presumed $\mathrm{P}$ scarcity. The main driver of the dynamics observed was $\mathrm{NH}_{4}{ }^{+}$. With regard to future deposition scenarios, a restriction of $\mathrm{N}$ production and emission amounts could potentially alter the lake dynamics if the deposited $\mathrm{N}$ form shifts towards a relatively higher $\mathrm{NH}_{4}{ }^{+}$deposition. Higher $\mathrm{NH}_{4}{ }^{+}$ratios may increase the chlorophyll $a$ concentrations and affect the growth of certain phytoplankton groups, together with the phytoplankton resource use efficiency. Such a change might also promote shifts towards higher proportions of small green algae, especially flagellated species (such as Chlamydomonas $s p$. in our experiment). A shift towards the more efficient utilization of $\mathrm{P}$, combined with a shift towards highly-edible algae such as Chlamydomonas sp., could result in greater zooplankton production and thus greater planktivorous fish production in P-limited lakes as $\mathrm{NH}_{4}{ }^{+}$input increases. Changes in the supply ratio of $\mathrm{N}$ sources can therefore alter aquatic food webs, even in ecosystems where the element is not a limiting factor per se. Consequently, $\mathrm{N}$ management, as part of conservation strategies to ensure sustainable ecosystem functioning and services, should include not only $\mathrm{N}$-limited ecosystems, but also largely P-limited freshwater lakes (Harpole et al. 2011; Lewis et al. 2011; Paerl et al. 2011, 2016).

Acknowledgements Open Access funding provided by Projekt DEAL. We are grateful for the technical assistance of A. Wild and A. Weigert, as well as P. Lorenz and students for help in running the experiment. We also thank two anonymous reviewers for their constructive comments that have greatly improved this paper. This study was funded by the German Research Foundation grant Tr 1126/1-1) to GT and the European grant FP 2007 CIG Microdive to HS. MP was funded by Cusanuswerk.

\section{Compliance with ethical standards}

Conflict of interest The authors declare that they have no conflict of interest.

Open Access This article is licensed under a Creative Commons Attribution 4.0 International License, which permits use, sharing, adaptation, distribution and reproduction in any medium or format, as long as you give appropriate credit to the original author(s) and the source, provide a link to the Creative Commons licence, and indicate if changes were made. The images or other third party material in this article are included in the article's Creative Commons licence, unless indicated otherwise in a credit line to the material. If material is not included in the article's Creative Commons licence and your intended use is not permitted by statutory regulation or exceeds the permitted use, you will need to obtain permission directly from the copyright holder. To view a copy of this licence, visit http://creativecommons.org/licenses/by/4.0/.

\section{References}

Aksnes DL, Egge JK (1991) A theoretical model for nutrient uptake in phytoplankton. Mar Ecol Prog Ser 70:65-72

Axler RP, Reuter JE (1996) Nitrate uptake by phytoplankton and periphyton : whole-lake enrichments and mesocosm-15N experiments in an oligotrophic lake. Limnol Oceanogr 41:659-671

Bergström A-K, Jansson M (2006) Atmospheric nitrogen deposition has caused nitrogen enrichment and eutrophication of lakes in the northern hemisphere. Glob Change Biol 12:635-643

Bergström A-K, Blomqvist P, Jansson M (2005) Effects of atmospheric nitrogen deposition on nutrient limitation and phytoplankton biomass in unproductive Swedish lakes. Limnol Oceanogr 50:987-994

Beutler M, Wiltshire KH, Meyer B, Moldaenke C, Lüring C, Meyerhöfer M, Hansen U-P, Dau H (2002) A fluorometric method for the differentiation of algal populations in vivo and in situ. Photosynth Res 72:39-53

Blomqvist P, Pettersson A, Hyenstrand P (1994) Ammonium-nitrogen-a key regulatory factor causing dominance of non-nitrogen-fixing cyanobacteria in aquatic systems. Arch Hydrobiol 132:141-164

Bouwman L, Goldewijk KK, Van Der Hoek KW, Beusen AHW, Van Vuurena DP, Willems J, Rufino MC, Stehfest E (2013) Exploring global changes in nitrogen and phosphorus cycles in agriculture induced by livestock production over the 1900-2050 period. PNAS 110:20882-20887. https://doi.org/10.1073/pnas.10128 78108

Bracken MES, Hillebrand H, Borer ET, Seabloom EW, Cebrian J, Cleland EE, Elser JJ, Gruner DS, Harpole WS, Ngai JT, Smith JE (2015) Signatures of nutrient limitation and co-limitation: responses of autotroph internal nutrients concentrations to nitrogen and phosphorus additions. Oikos 124:113-121

Ciais P, Sabine C, Bala G, Bopp L, Brovkin V, Canadell J, Chhabra A, DeFries R, Galloway J, Heimann M, Jones C, Le Quéré C, Myneni RB, Piao S, Thornton P (2013) Carbon and other biogeochemical cycles. In: Stocker TF, Qin D, Plattner G-K, Tignor M, Allen SK, Boschung J, Nauels A, Xia Y, Bex V, Midgley PM (eds) Climate change 2013: the physical science basis. Contribution of working group I to the fifth assessment report of the intergovernmental panel on climate change. Cambridge University Press, Cambridge. 
Cochlan WP, Harrison PJ (1991) Inhibition of nitrate uptake by ammonium and urea in the eukaryotic picoflagellate Micromonas pusilla (Butcher) Manton et Parke. J Exp Mar Biol Ecol 153:143-152

Diaz RJ, Rosenberg R (2008) Spreading dead zones and consequences for marine ecosystems. Science 321:926-930

Domingues RB, Barbosa AB, Sommer U, Galvao HM (2011) Ammonium, nitrate and phytoplankton interactions in a freshwater tidal estuarine zone: potential effects of cultural eutrophication. Aquat Sci 73:331-343

Donald DB, Bogard MJ, Finlay K, Leavitt PR (2011) Comparative effects of urea, ammonium, and nitrate on phytoplankton abundance, community composition, and toxicity in hypereutrophic freshwaters. Limnol Oceanogr 56:2161-2175

Donald DB, Bogard MJ, Finlay K, Bunting L, Leavitt PR (2013) Phytoplankton-specific response to enrichment of phosphorus-rich surface waters with ammonium, nitrate, and urea. PLoS ONE 8:e53277

Dortch Q (1990) The interaction between ammonium and nitrate uptake in phytoplankton. Mar Ecol Prog Ser 61:183-201

Dortch Q, Conway H (1984) Interactions between nitrate and ammonium uptake: variation with growth rate, nitrogen source and species. Mar Biol 79:151-164

Duce RA, LaRoche J, Altieri K, Arrigo KR, Baker AR, Capone DG, Cornell S, Dentener F et al (2008) Impacts of atmospheric anthropogenic nitrogen on the open ocean. Science 320:893-897

Dugdale RC, Wilkerson FP, Hogue VE, Marchi A (2007) The role of ammonium and nitrate in spring bloom development in San Francisco Bay. Estuar Coast Shelf Sci 73:17-29

Dugdale RC, Wilkerson FP, Parker AE, Marchia A, Taberski K (2012) River flow and ammonium discharge determine spring phytoplankton blooms in an urbanized estuary. Estuar Coast Shelf Sci 115:187-199. https://doi.org/10.1016/j.ecss.2012.08.025

Edwards KF, Klausmeier CA, Litchman E (2011) Evidence for a threeway trade-off between nitrogen and phosphorus competitive abilities and cell size in phytoplankton. Ecology 92:2085-2095

Elser JJ, Bracken MES, Cleland EE, Gruner DS, Harpole WS, Hillebrand H, Ngai JT, Seabloom EW, Shurin JB, Smith JE (2007) Global analysis of nitrogen and phosphorus limitation of primary producers in freshwater, marine and terrestrial ecosystems. Ecol Lett 10:1-8. https://doi.org/10.1111/j.1461-0248.2007.01113.x

Eppley RW, Coatsworth JL, Solorzano L (1969a) Studies of nitrate reductase in marine phytoplankton. Limnol Oceanogr 14:194-205

Eppley RW, Rogers JN, McCarthy JJ (1969b) Half-saturation constants for uptake of nitrate and ammonium by marine phytoplankton. Limnol Oceanogr 14:912-920

Falkowski PG (1975) Nitrate uptake in marine phytoplankton: comparison constants from seven specie. Limnol Oceanogr 20:412-417

Flores E, Herrero A (2005) Nitrogen assimilation and nitrogen control in cyanobacteria. Biochem Soc Trans 33:164-167

Galloway JN, Aber JD, Erisman JW, Seitzinger SP, Howarth RW, Cowling EB, Cosby BJ (2003) The nitrogen cascade. Bioscience 53:341-356

Galloway JN, Dentener FJ, Capone DG, Boyer EW, Howarth RW, Seitzinger SP, Asner GP, Cleveland CC, Green PA, Holland EA, Karl DM, Michaelis AF, Porter JH, Townsend AR, Vörösmarty CJ (2004) Nitrogen cycles: past, present, and future. Biogeochemistry 70:153-226

Glibert PM, Wilkerson FP, Dugdale RC, Raven JA, Dupont CL, Leavitt PR, Parker AE, Burkholder JM et al (2016) Pluses and minuses of ammonium and nitrate uptake and assimilation by phytoplankton and implications for productivity and community composition, with emphasis on nitrogen enriched conditions. Limnol Oceanogr 61:165-197

Gruber N, Galloway JN (2008) An earth-system perspective of the global nitrogen cycle. Nature 451:293-296
Harpole WS, Ngai JT, Cleland EE, Seabloom EW, Borer ET, Bracken MES, Elser JJ, Gruner DS, Hillebrand H, Shurin JB, Smith JE (2011) Nutrient co-limitation of primary producer communities. Ecol Lett 14:852-862

Hein M, Pedersen M, Sand-Jensen K (1995) Size-dependent nitrogen uptake in micro- and macroalgae. Mar Ecol Prog Ser 118:247-253

Hii Y, Soo C, Chuah T, Mohd-Azmi A, Abol-Munafi A (2011) Interactive effect of ammonia and nitrate on the nitrogen uptake by Nannochloropsis sp. J Sustain Sci Manage 6:60-68

Hillebrand H, Durselen CD, Kirschtel D, Pollingher U, Zohary T (1999) Biovolume calculation for pelagic and benthic microalgae. J Phycol 35:403-424

Holmes RM, Aminot A, Kerouel R, Hooker BA, Peterson BJ (1999) A simple and precise method for measuring ammonium in marine and freshwater ecosystems. Can J Fish Aquat Sci 56:1801-1808

Hutchins DA, Pustizzi F, Hare CE, DiTullio GR (2003) A shipboard natural community continuous culture system for ecologically relevant low-level nutrient enrichment experiments. Limnol Oceanogr-Meth 1:82-91

Kim I-N, Lee K, Gruber N, Karl DM, Bullister JL, Yang S, Kim T-W (2014) Increasing anthropogenic nitrogen in the North Pacific Ocean. Science 346:1102-1106

Klausmeier C, Litchman E, Daufresne T, Levin SA (2004) Optimal nitrogen-to-phosphorus stoichiometry of phytoplankton. Nature 429:171-174

LeBauer DS, Treseder KK (2008) Nitrogen limitation of net primary productivity in terrestrial ecosystems is globally distributed. Ecology 89:371-379

Levasseur M, Thompson PA, Harrison PJ (1993) Physiological acclimation of marine phytoplankton to different nitrogen sources. J Phycol 29:587-595

Lewis WM, Wurtsbaugh WA, Paerl HW (2011) Rationale for control of anthropogenic nitrogen and phosphorus to reduce eutrophication of inland waters. Environ Sci Technol 45:10300-10305

Litchman E, Klausmeier C, Schofield O, Falkowski P (2007) The role of functional traits and trade-offs in structuring phytoplankton communities: scaling from cellular to ecosystem level. Ecol Lett 10:1170-1181

Lomas MW (2004) Nitrate reductase and urease enzyme activity in the marine diatom Thalassiosira weissflogii (Bacillariophyceae): interactions among nitrogen substrates. Mar Biol 144:37-44

Lorenz P, Trommer G, Stibor H (2019) Impacts of increasing nitrogen:phosphorus ratios on zooplankton community composition and whitefish (Coregonus macrophthalmus) growth in a pre-alpine lake. Freshwater Biol 00:1-16. https://doi.org/10.1111/ fwb.13296

Maxwell K, Johnson GN (2000) Chlorophyll fluorescence-a practical guide. J Exp Bot 51:659-668

McCarthy MJ, James RT, Chen Y, East TL, Gardner WS (2009) Nutrient ratios and phytoplankton community structure in the large, shallow, eutrophic, subtropical Lakes Okeechobee (Florida, USA) and Taihu (China). Limnol 10:215-227

Paerl HW (1997) Coastal eutrophication and harmful algal blooms : Importance of atmospheric deposition and groundwater as "new" nitrogen and other nutrient sources. Limnol Oceanogr 42:1154-1165

Paerl HW, Huisman J (2008) Blooms Like It Hot. Science 320:57-58

Paerl HW, Xu H, McCarthy MJ, Zhu G, Qin B, Li Y, Gardner WS (2011) Controlling harmful cyanobacterial blooms in a hypereutrophic lake (Lake Taihu, China): The need for a dual nutrient (N \& P) management strategy. Water Res 45:1973-1983

Paerl HW, Gardner WS, McCarthy MJ, Peierls BL, Wilhelm SW (2014) Algal blooms: Noteworthy nitrogen. Science 346:175-176

Paerl HW, Scott JT, McCarthy MJ, Newell SE, Gardner WS, Havens KE, Hoffmann DK, Wilhelm SW, Wurtsbaugh WA (2016) It takes 
two to tango: when and where dual nutrient $(\mathrm{N} \& \mathrm{P})$ reductions are needed to protect lakes and downstream ecosystems. Environ Sci Technol 50:10805-10813

Poxleitner M, Trommer G, Lorenz P, Stibor H (2016) The effect of increased nitrogen load on phytoplankton in a phosphorus-limited lake. Fresh Biol 61:1966-1980

Ptacnik R, Solimini AG, Andersen T, Tamminen T, Brettum P, Lepistö L, Willén E, Rekolainen S (2008) Diversity predicts stability and resource use efficiency in natural phytoplankton communities. PNAS 105:5134-5138

Radzun KA, Wolf J, Jakob G, Zhang E, Stephens E, Ross I, Hankamer B (2015) Automated nutrient screening system enables highthroughput optimisation of microalgae production conditions. Biotechnol Biofuels 8:65. https://doi.org/10.1186/s13068-015-0238-7

Raven JA, Wollenweber B, Handley LL (1992) A comparison of ammonium and nitrate as nitrogen source for photolithotrophs. New Phytol 121:19-32

Smith REH, Kalff J (1982) Size-dependent phosphorus uptake kinetics and cell quota in phytoplankton. J Phycol 18:275-284

Sommer U (1985) Comparison between steady state and non-steady state competition: Experiments with natural phytoplankton. Limnol Oceanogr 30:335-346

Sommer U (1993) Phytoplankton competition in Plußsee: a field test of the resource-ratio hypothesis. Limnol Oceanogr 38:838-845

Song B, Ward BB (2004) Molecular characterization of the assimilatory nitrate reductase gene and its expression in the marine green algae Dunaliella tertiolecta (Chlorophyceae). J Phycol 40:721-731

Steffen W, Richardson K, Rockström J, Cornell E, Fetzer I, Bennett EM, Biggs R, Carpenter SR et al (2015) Planetary boundaries: guiding human development on a changing planet. Science. https ://doi.org/10.1126/science.1259855

Sterner RW, Andersen T, Elser JJ, Hessen DO, Hood JM, McCauley E, Urabe J (2008) Scale-dependent carbon:nitrogen:phosphorus seston stoichiometry in marine and freshwaters. Limnol Oceanogr 53:1169-1180

Stolte W, Riegman R (1995) Effect of phytoplankton cell size on transient- state nitrate and ammonium uptake kinetics. Microbiology 141:1221-1229
Syrett PJ (1981) Nitrogen metabolism of microalgae. In: Platt T (ed) Physiological bases of phytoplankton ecology. Can Bull Fish Aquat Sci 210:182-210

Tilman D (1977) Resource competition between planktonic algaeexperimental and theoretical approach. Ecology 58:338-348

Trommer G, Poxleitner M, Lorenz P, Bitzilekis E, Gogaladze A, Schultes S, Stibor H (2017) Altered food-web dynamics under increased nitrogen load in phosphorus deficient lakes. Aquat Sci 79:10091021. https://doi.org/10.1007/s00027-017-0551-2

Twomey LJ, Piehler MF, Paerl HW (2005) Phytoplankton uptake of ammonium, nitrate and urea in the Neuse River Estuary, NC, USA. Hydrobiologia 533:123-134

Uthermöhl H (1958) Zur Vervollkommnung der quantitativen Phytoplanktonmethodik. Mitteil Int Verein Limn 9:1-38

Vitousek PM, Howarth RW (1991) Nitrogen limitation on land and in the sea-how can it occur? Biogeochemistry 13:87-115

Vitousek PM, Porder S, Houlton BZ, Chadwick OA (2010) Terrestrial phosphorus limitation: mechanisms, implications, and nitrogenphosphorus interactions. Ecol Appl 20:5-15

Wafar M, L'Helguen S, Raikar V, Maguer J-F, Le Corre P (2004) Nitrogen uptake by size-fractionated plankton in permanently wellmixed temperate coastal waters. J Plankton Res 26:1207-1218

Wetzel RG, Likens GE (1991) Limnological analyses, 2nd edn. Springer Verlag, Heidelberg, Germany

Yoshiyama K, Sharp JH (2006) Phytoplankton response to nutrient enrichment in an urbanized estuary: apparent inhibition of primary production by overeutrophication. Limnol Oceanogr 51:424-434. https://doi.org/10.4319/lo.2006.51.1_part_2.0424

Publisher's Note Springer Nature remains neutral with regard to jurisdictional claims in published maps and institutional affiliations. 